\title{
Is there a variance in complication types associated with ALIF approaches? A systematic review
}

\author{
Aoife Feeley ${ }^{1,2}$ (1) $\cdot$ lain Feeley ${ }^{3} \cdot$ Kevin Clesham ${ }^{4} \cdot J^{\prime}$ oseph Butler ${ }^{3}$
}

Received: 23 August 2021 / Accepted: 8 September 2021 / Published online: 21 September 2021

(c) The Author(s) 2021, corrected publication 2022

\begin{abstract}
Purpose Anterior lumbar interbody fusion (ALIF) is a well-established alternative to posterior-based interbody fusion techniques, with approach variations, such as retroperitoneal, transperitoneal, open, and laparoscopic well described. Variable rates of complications for each approach have been enumerated in the literature. The purpose of this study was to elucidate the comparative rates of complications across approach type.

Methods A systematic review of search databases PubMed, Google Scholar, and OVID Medline was made to identify studies related to complication-associated ALIF. PRISMA guidelines were utilised for this review. Meta-analysis was used to compare intraoperative and postoperative complications with ALIF for each approach.

Results A total of 4575 studies were identified, with 5728 patients across 31 studies included for review following application of inclusion and exclusion criteria. Meta-analysis demonstrated the transperitoneal approach resulted in higher rates of retrograde ejaculation (RE) $(p<0.001 ; \mathrm{CI}=0.05-0.21)$ and overall rates of complications $(p=0.05 ; \mathrm{CI}=0.00-0.23)$. Rates of RE were higher at the L5/S1 intervertebral level. Rates of vessel injury were not significantly higher in either approach method $(p=0.89 ; \mathrm{CI}=-0.04-0.07)$. Rates of visceral injury did not appear to be related to approach method. Laparoscopic approaches resulted in shorter inpatient stays $(p=0.01)$.

Conclusion Despite the transperitoneal approach being comparatively underpowered, its use appears to result in a significantly higher rate of intraoperative and postoperative complications, although confounders including use of bone morphogenetic protein (BMP) and spinal level should be considered. Laparoscopic approaches resulted in shorter hospital stays; however, its steep learning curve and longer operative time have deterred surgeons from its widespread adaptation.
\end{abstract}

Keywords Anterior lumbar interbody fusion $\cdot$ Approach $\cdot$ Complications $\cdot$ Outcomes

\section{Introduction}

The anterior approach to the lumbar spine affords excellent exposure, most commonly applied to the lower lumbar levels (L5/S1 and L4/5) [12]. The specific benefits of this

This article is part of the Topical Collection on Spine degenerative

Aoife Feeley

aoifefy@gmail.com

1 Midland Regional Hospital Tullamore, Arden Rd, Puttaghan, Tullamore, Co. Offaly R35 NY51, Ireland

2 University College Dublin, Belfield, Dublin 4, Ireland

3 Mater Misericordiae University Hospital, Eccles St, Dublin 7 D07 R2WY, Ireland

4 National Orthopaedic Hospital Cappagh, Cappagh Rd, Cappoge, Dublin 11 D11 EV29, Ireland approach at these levels include enabling greater volume of disc removal [36] with excellent preparation of the endplates prior to insertion of an interbody cage or graft [53], thereby allowing increased contact surface area for better fusion rates [74]. Lower operative blood loss and operative times have been reported when compared to posterior approaches [24], in addition to a reduced risk of adjacent segmental disease [49]. The avoidance of thecal sac manipulation inherently reduces risk of dural injury [61]. The advantages conferred by the anterior approach have made it an increasingly popular option for a variety of conditions including degenerative disc disease, spondylolisthesis, spinal deformity [23], and infection [53].

Acceleration of surgical techniques has been achieved through a myriad of avenues including preoperative planning using 3D printed patient specific dimensions, virtual reality-based simulation training, and advancements in 
surgical instruments used intraoperatively. The introduction of the DaVinci Robot by access surgeons in the approach to the anterior lumbar spine has yielded positive surgical outcomes [22]. A growing area of interest is current implant use, which has been the recent focus in research to enhance osteointegration to achieve better fusion rates [37]. Novel techniques in spinal fusion have recently been explored to minimise patient complications and hospital length of stay, with computer-assisted navigation used to increase accuracy of pedicle screw placement compared to freehand placement [47]. Efforts to mitigate against complications associated with the procedure have led to the development of variations on the surgical approach [63]. In particular, risk of to the great vessels is inherent in their mobilisation [57], whilst also at risk are the peritoneal visceral contents [30] and the ureter [30]. Damage to the hypogastric plexus may result in retrograde ejaculation in men [20]. Adequate positioning of interbody devices and minimising risk of device migration are also considerations in the type of anterior approach undertaken [1].

The goal of this review is to systematically analyse the literature to determine the rates of complications associated with the variations in the anterior approach in lumbar interbody fusion (ALIF) and other quantitative comparisons that exist within available evidence.

\section{Methods}

\section{Search strategy}

A systematic search in accordance with Preferred Reporting Items for Systematic reviews and Meta-Analysis (PRISMA [55]) guidelines was made of electronic databases including PubMed, OVID Medline, and Google Scholar, with study selection identification up to November 2020 (Fig. 1). Broad search terms to ensure adequate capture were used, using a combination of "Anterior Lumbar Interbody", "ALIF", "Complications", "Lumbar Interbody Fusion" as keywords or MeSH search terms. This study was registered with PROSPERO under registration number: CRD42020220449.

Abstracts of relevant titles were read, with inclusion and exclusion criteria applied (Table 1), and if the inclusivity of the study was uncertain the study was read in full. Reference lists of included articles were evaluated for any additional research suitable for assessment. Data extraction was carried out independently by two reviewers (AF, IF), with 2 and 8 years specialty training completed including dedicated spinal unit residency rotations undertaken. Results were collated and presented in a systematic fashion below.

Study quality was assessed using the Risk of Bias Tools as per Cochrane guidelines.

Ad hoc tables were designed to summarise data from the included studies and show their key characteristics including method of fusion and use of access surgeons (Table 2) and any important questions related to the aim of this review

Fig. 1 PRISMA flowchart

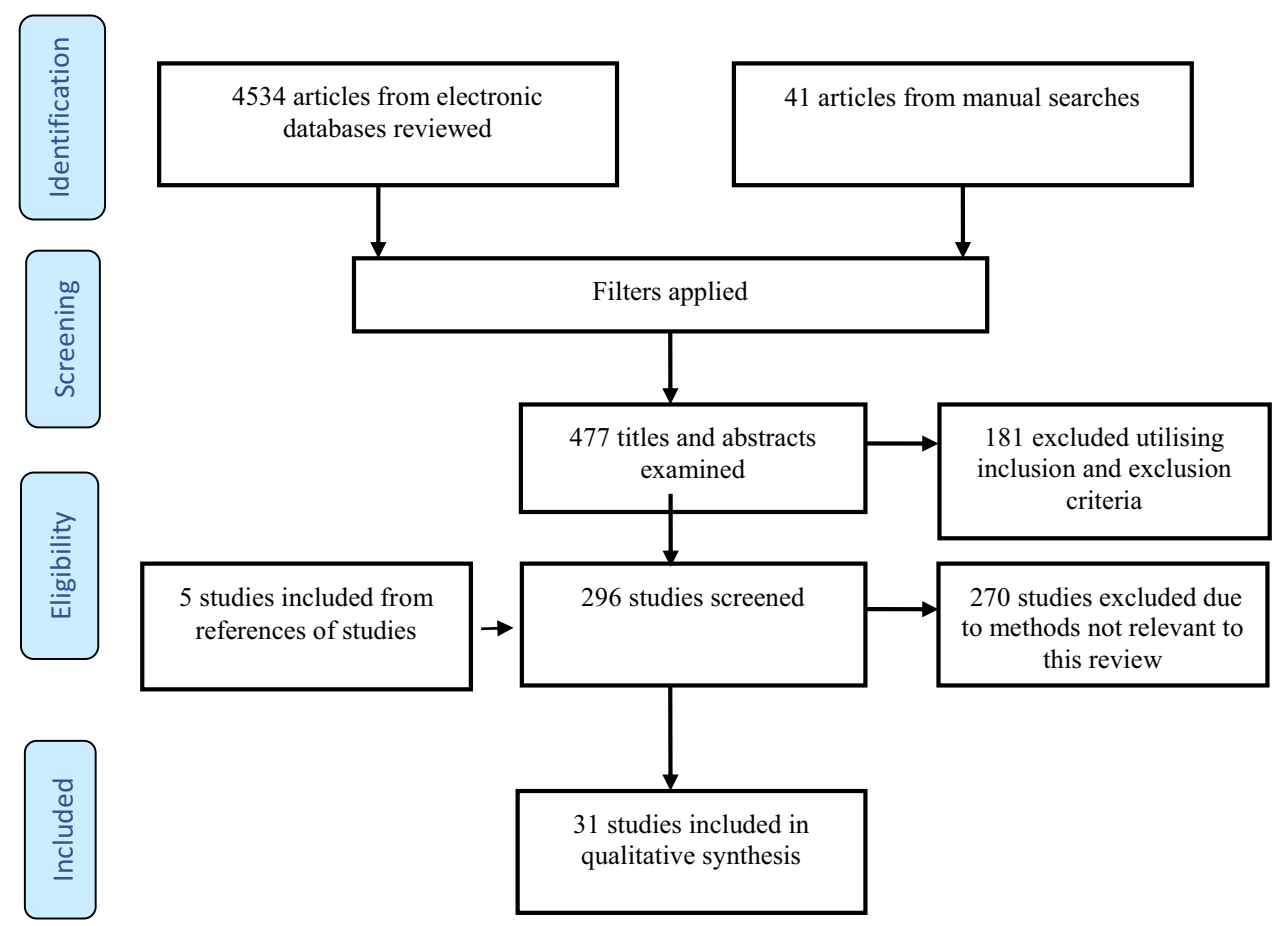


Table 1 Inclusion and exclusion criteria

\begin{tabular}{lll}
\hline Review criteria & Inclusion & Exclusion \\
\hline Patient population & $>18$, anterior interbody fusion, & $<18$, oblique or lateral approaches \\
Study types & In vivo & Systematic reviews, case reports \\
Level of evidence & $<$ IV & $\geq$ IV \\
Publication type & Peer reviewed, English & Abstracts, letters \\
Operative methods & ALIF only & Mixed approaches, disc arthro- \\
& & plasty, unclear methods \\
\hline
\end{tabular}

Table 2 Studies by approach method

\begin{tabular}{lll}
\hline & Laparoscopic/other & Open \\
\hline Transperitoneal & 2 & 0 \\
Retroperitoneal & 3 & 16 \\
Mixed methods & 10 & \\
\hline
\end{tabular}

(Tables 3 and 4). Complication rates for operative metrics, access complications, and overall complications were pooled for inter-group analysis. Meta-analysis on rates of retrograde ejaculation and vascular injuries was carried out using RevMan 5.4 using a fixed effects method to evaluate risk difference between approach groups. A difference in complication rates with a $p$ value of $<0.05$ was taken as significant.

\section{Results}

Our search yielded 4575 publications. The 31 studies satisfying inclusion criteria included a total of 5728 patients, 5408 undergoing and ALIF via a retroperitoneal approach, 320 via a transperitoneal approach, with methods enumerated below (Table 2).

Included studies in this review consisted of two randomised control trials: 10 prospective cohort studies and 19 retrospective studies. There was a trend toward the retroperitoneal approach with all study methodologies. Bias was assessed using Cochrane recommended tools for systematic reviews, with no studies deemed high risk during assessment. Non-randomised control trials studies were assessed using ROBINS-I tool, generally demonstrating unclear risk in relation to missing data, measurement of outcomes, and bias in selection of reported results, in part due to the study methodologies of retrospective data collection.

\section{Complications}

Simple pooling of outcomes evaluated was carried out across studies included for review to assess perioperative and postoperative outcomes between approach methods. Complications included for analysis included rates of RE, vascular injury, haematological complications including deep venous thrombosis and haematoma formation, injury to the viscera, development of Dural tears, wound infections, hernias, and the incidence of postoperative ileus. Total patients included per group were used for analysis, except rates of RE. Where no gender breakdown was available in the studies, complication and patient population were excluded, with results summarised below (Table 5).

\section{Meta-analysis}

Meta-analysis of studies directly comparing transperitoneal and retroperitoneal approaches for overall complications, rates of retrograde ejaculation (RE), and vessel injury was carried out, with 5 studies included for analysis of RE and 3 studies comparing vascular outcomes, and overall outcomes between approaches. An $I^{2}$ value of 0-41\% demonstrated for all comparisons, demonstrating moderate homogeneity.

\section{Retrograde ejaculation}

Comparative studies demonstrated a significantly higher risk of RE (Fig. 2) using the transperitoneal approach $(p<0.001$; $\mathrm{CI}=0.05-0.21)$.

\section{Vessel injury}

Number of vessel complications in comparative studies had a generally low reporting (Fig. 3); however, rates of vessel injury by approach were not found to be significant $(p=0.89 ; \mathrm{CI}=-0.04-0.07)$.

\section{Overall complications}

Data regarding overall complications (Fig. 4) was reported in only 3 comparative studies. The mean number of peri and postoperative complications in the retroperitoneal $(n=5)$ and transperitoneal $(n=6)$ groups, respectively, with this difference deemed not statistically significant $(p=0.05$; $\mathrm{CI}=0.00-0.23)$. The $I^{2}$ value was $41 \%$. 


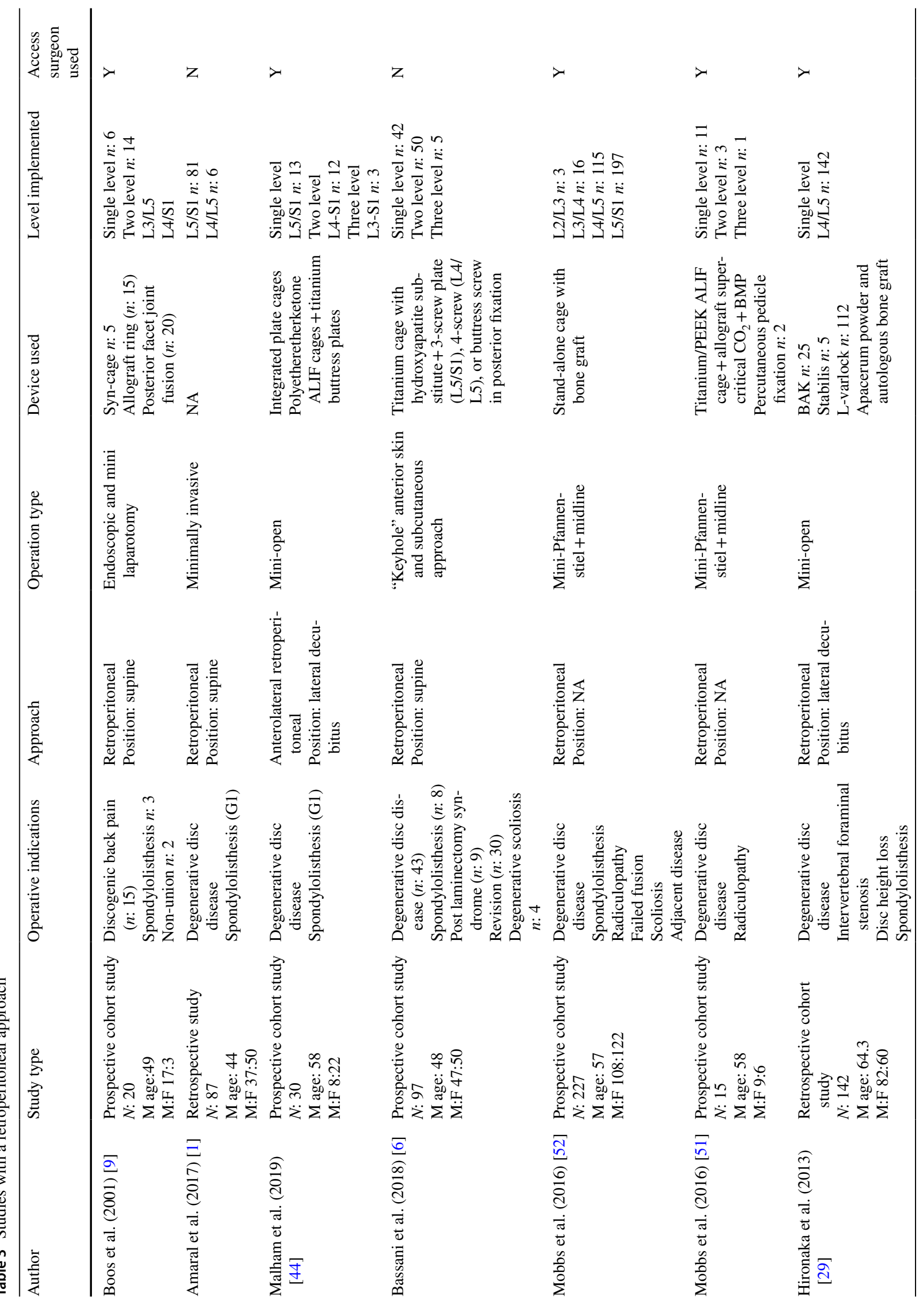




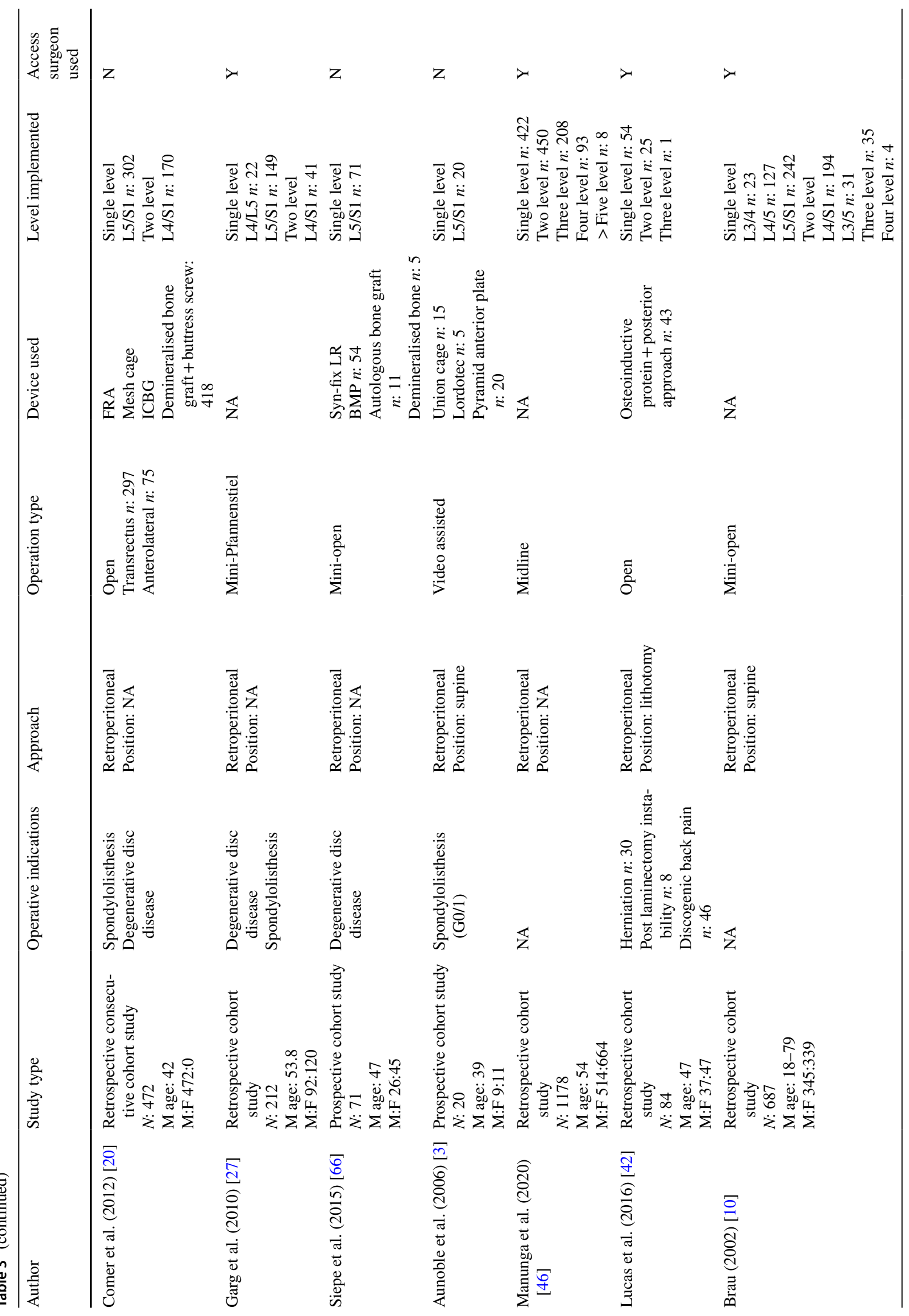




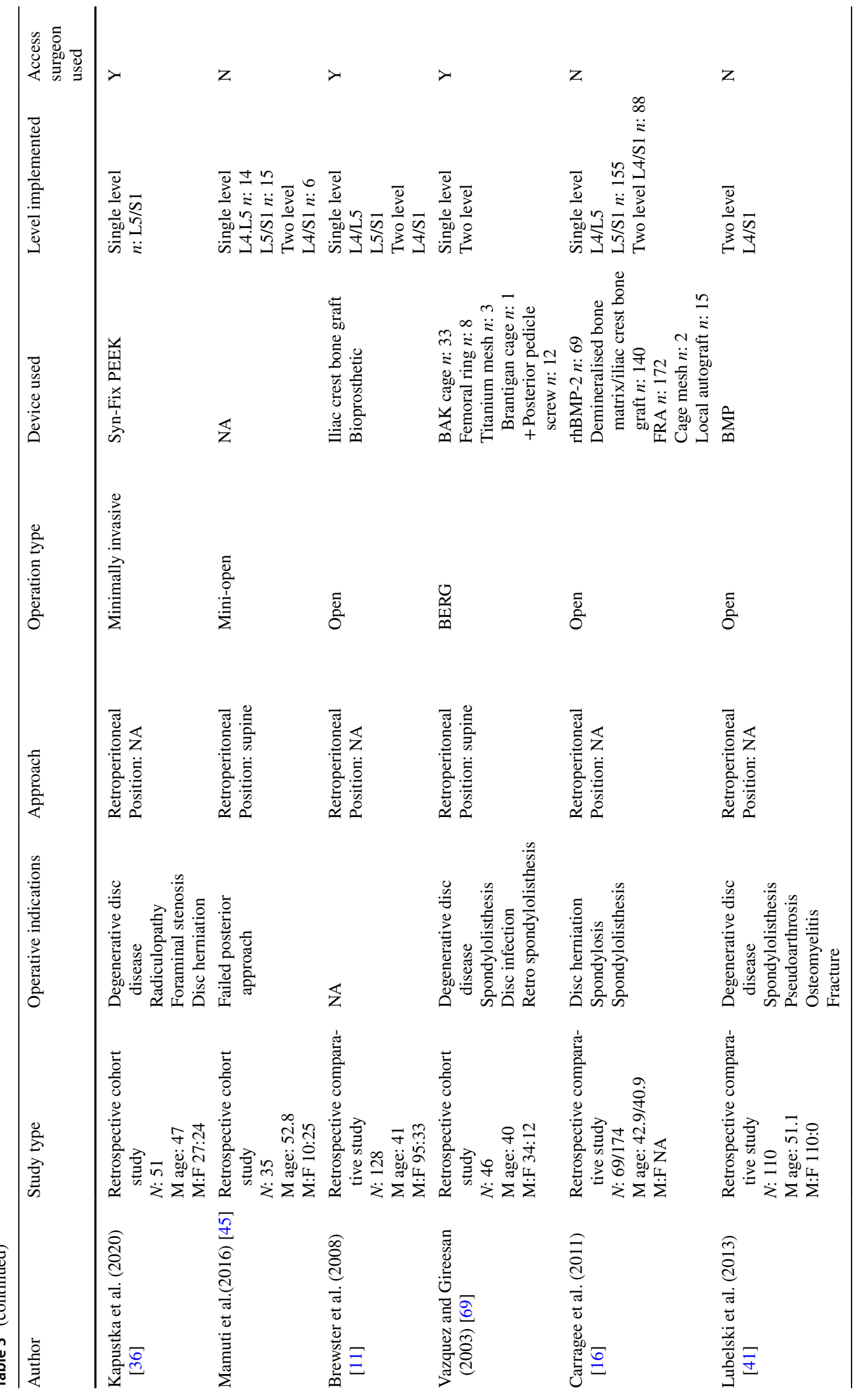


Table 4 Retroperitoneal and mixed methods studies

\begin{tabular}{|c|c|c|c|c|c|c|c|}
\hline $\begin{array}{l}\text { Sasso et al. } \\
\text { (2003) [65] }\end{array}$ & $\begin{array}{l}\text { Prospective } \\
\text { comparative } \\
\text { study } \\
N: 146 \\
\text { M:F } 146: 0\end{array}$ & $\begin{array}{l}\text { Degenerative } \\
\text { disc disease }\end{array}$ & $\begin{array}{l}\text { Retroperitoneal } \\
n: 116 \\
\text { Transperitoneal } \\
n: 30 \\
\text { Position: supine }\end{array}$ & Open & $\begin{array}{l}\text { rhBMP-2 ( } n: \\
78) \\
\text { Iliac crest bone } \\
\text { graft }(n: 68)\end{array}$ & $\begin{array}{l}\text { One level L4/L5 } \\
\text { or L5/S1 }\end{array}$ & $\mathrm{Y}$ \\
\hline $\begin{array}{l}\text { Kaiser et al. } \\
\text { (2002) [35] }\end{array}$ & $\begin{array}{l}\text { Retrospective } \\
\text { comparative } \\
\text { study } \\
N: 98 \\
\text { M age: } 43 \\
\text { M:F 43:55 }\end{array}$ & $\begin{array}{l}\text { DDD spon- } \\
\text { dylolisthesis } \\
\text { (G1) Pseu- } \\
\text { doarthrosis } \\
\text { multiple } \\
\text { diagnoses }\end{array}$ & $\begin{array}{c}\text { Transperitoneal } \\
{[35,48]} \\
\text { Position: NA }\end{array}$ & $\begin{array}{l}\text { Laparoscopic } \\
n: 47 \\
\text { Mini-open } n: 51\end{array}$ & NA & $\begin{array}{l}\text { Single level } \\
\quad n: 88 \\
\text { L5/S1 } n: 81 \\
\text { L4/L5 } n: 7 \\
\text { Two level } n: 10 \\
\text { L4/S1 } n: 9 \\
\text { L3/L5 } n: 1\end{array}$ & $\mathrm{Y}$ \\
\hline $\begin{array}{l}\text { Frantzides et al. } \\
\text { (2006) [26] }\end{array}$ & $\begin{array}{l}\text { Retrospective } \\
\text { cohort study } \\
N: 28 \\
\text { M age: } 43 \\
\text { M:F } 15: 13\end{array}$ & $\begin{array}{l}\text { Degenerative } \\
\text { disc disease } \\
\text { spondylolis- } \\
\text { thesis post } \\
\text { laminectomy } \\
\text { syndromes }\end{array}$ & $\begin{array}{l}\text { Transperitoneal } \\
\text { Position: Tren- } \\
\text { delenburg }\end{array}$ & Laparoscopic & $\begin{array}{l}\text { BAK } \\
\text { RAY } \\
\text { Lordotic LT } \\
\text { cages } \\
\text { Iliac bone } \\
\text { graft + BMP } \\
\text { Posterior } \\
\text { pedicle screw } \\
n: 10\end{array}$ & $\begin{array}{l}\text { Single level } \\
\text { L5/S1 } n: 28\end{array}$ & $\mathrm{Y}$ \\
\hline $\begin{array}{l}\text { Escobar et al. } \\
\text { (2003) [25] }\end{array}$ & $\begin{array}{l}\text { Retrospective } \\
\text { comparative } \\
\text { study } \\
N: 135 \\
\text { M age: } 43 \\
\text { M:F 50:85 }\end{array}$ & $\begin{array}{l}\text { Degenerative } \\
\text { disc disease } \\
\text { Spondylolis- } \\
\text { thesis } \\
\text { Previous fusion } \\
\text { pseudoarthrosis }\end{array}$ & $\begin{array}{l}\text { Retroperitoneal } \\
\text { vídeo assisted } \\
n: 30 \\
\text { Transperitoneal } \\
\text { insufflation } \\
n: 34 \\
\text { Position: NA }\end{array}$ & $\begin{array}{l}\text { Retroperitoneal: } \\
\text { open }(\mathrm{G} 4)(n \text { : } \\
20) \\
\text { Video assisted } \\
(\mathrm{G} 2)(n: 30) \\
\text { Transperitoneal } \\
\text { insufflation } \\
(\mathrm{G} 1)(n: 34) \\
\text { Mini-lap } \\
\text { extraperitoneal } \\
(\mathrm{G} 3)(n: 30)\end{array}$ & $\begin{array}{l}\text { Cylindrical cage } \\
\text { Bone grafting }\end{array}$ & NA & $\mathrm{Y}$ \\
\hline $\begin{array}{l}\text { Cowles et al. } \\
(2000) \text { [21] }\end{array}$ & $\begin{array}{l}\text { Retrospective } \\
\text { comparative } \\
\text { study } \\
N: 75 \\
\text { M age: } 45 / 41 \\
\text { M:F 33:43 }\end{array}$ & $\begin{array}{l}\text { Degenerative } \\
\text { disc disease } \\
\text { Failed previous } \\
\text { surgery }\end{array}$ & $\begin{array}{l}\text { Transperitoneal } \\
\text { Position: Tren- } \\
\text { delenburg }\end{array}$ & $\begin{array}{l}\text { Laparoscopic } \\
n: 55+\text { open } \\
n: 20\end{array}$ & NA & NA & $\mathrm{Y}$ \\
\hline $\begin{array}{l}\text { Burkus et al. } \\
\text { (2002) [14] }\end{array}$ & $\begin{array}{l}\text { RCT } \\
N: 279 \\
\text { M age: } 43.3 \\
\text { M:F 146:133 }\end{array}$ & $\begin{array}{l}\text { Degenerative } \\
\text { disc disease } \\
\text { Spondylolis- } \\
\text { thesis }\end{array}$ & $\begin{array}{l}\text { Retroperitoneal } \\
n: 226+\text { trans- } \\
\text { peritoneal } \\
n: 53 \\
\text { Position: supine }\end{array}$ & Open & $\begin{array}{l}\text { LT-CAGE } \\
\text { BMP } n: 143 \\
\text { Iliac crest bone } \\
\text { graft } n: 136\end{array}$ & $\begin{array}{l}\text { Single level } \\
\text { L4/L5 } n: 69 \\
\text { L5/S1 } n: 109 \\
\text { L5/L6 } n: 1\end{array}$ & $\mathrm{~N}$ \\
\hline $\begin{array}{l}\text { Lavelle et al. } \\
\text { (2014) [39] }\end{array}$ & $\begin{array}{l}\text { RCT } \\
N: 73 \\
\text { M age: } 44 \\
\text { M:F 32:42 }\end{array}$ & $\begin{array}{l}\text { Degenerative } \\
\text { disc disease } \\
\text { Discogenic back } \\
\text { pain }\end{array}$ & $\begin{array}{l}\text { Retroperitoneal } \\
n: 17 \text { Trans- } \\
\text { peritoneal } \\
n: 56 \\
\text { Position: NA }\end{array}$ & $\begin{array}{l}\text { Midline } \\
\text { (trans) + para- } \\
\text { median (retro) }\end{array}$ & $\begin{array}{l}\text { BAK } n: 32 \\
\text { SAC } n: 41 \\
\text { ICBG }\end{array}$ & $\begin{array}{l}\text { Single level } \\
\text { L4/L5 } n: 19 \\
\text { L5/S/1 } n: 37 \\
\text { Two level } \\
\text { L4/S1 } n: 17\end{array}$ & NA \\
\hline $\begin{array}{l}\text { Zdeblick and } \\
\text { David (2000) } \\
\text { [74] }\end{array}$ & $\begin{array}{l}\text { Prospective } \\
\text { comparative } \\
\text { study } \\
N: 50 \\
\text { M age: } 40.5 \\
\text { M:F } 24: 26\end{array}$ & $\begin{array}{l}\text { Discogenic pain } \\
\text { Pseudoarthrosis } \\
\text { Failed surgery }\end{array}$ & $\begin{array}{l}\text { Transperitoneal } \\
n: 25 \text { Retrop- } \\
\text { eritoneal } n: 25 \\
\text { Position: NA }\end{array}$ & $\begin{array}{l}\text { Laparoscopic } \\
n: 25+\text { mini- } \\
\text { open } n: 25\end{array}$ & $\begin{array}{l}\text { BAK } \\
\text { Lordotec } \\
\text { Femoral cortical } \\
\text { Interbody } \\
\text { fusion allo- } \\
\text { graft }\end{array}$ & $\begin{array}{l}\text { Single level L4/ } \\
\text { L5 }\end{array}$ & Y (Lap group) \\
\hline $\begin{array}{r}\text { Geerdes et al. } \\
\text { (2001) [28] }\end{array}$ & $\begin{array}{l}\text { Retrospective } \\
\text { cohort study } \\
N: 30 \\
\text { M age: } 43 \\
\text { M:F 8:22 }\end{array}$ & $\begin{array}{l}\text { Discogenic back } \\
\text { pain } \\
\text { Radiculopathy } \\
\text { Degenerative } \\
\text { disc disease }\end{array}$ & $\begin{array}{l}\text { Transperitoneal } \\
\text { Position: Tren- } \\
\text { delenburg }\end{array}$ & Laparoscopy & BAK & $\begin{array}{l}\text { Single level } \\
\text { L4/L5 } n: 3 \\
\text { L5/S1 } n: 25 \\
\text { Two level } \\
\text { L4/S1 } n: 2\end{array}$ & $\mathrm{Y}$ \\
\hline
\end{tabular}


Table 4 (continued)

\begin{tabular}{|c|c|c|c|c|c|c|c|}
\hline $\begin{array}{l}\text { Chung et al. } \\
\text { (2003) [19] }\end{array}$ & $\begin{array}{l}\text { Prospective } \\
\text { comparative } \\
\text { study } \\
N: 44 \\
\text { M age: } 49.5 \\
\text { M:F 11:33 }\end{array}$ & $\begin{array}{l}\text { Discogenic back } \\
\text { pain }\end{array}$ & $\begin{array}{l}\text { Transperitoneal } \\
n: 22 \text { Retrop- } \\
\text { eritoneal } n: 22 \\
\text { Position: NA }\end{array}$ & $\begin{array}{l}\text { Mini-open } n: 22 \\
\text { Laparoscopic } \\
n: 22\end{array}$ & $\begin{array}{l}\text { Brantigan car- } \\
\text { bon cage }\end{array}$ & $\begin{array}{l}\text { Single level } \\
\text { L5/S1 }\end{array}$ & Y (Lap group) \\
\hline $\begin{array}{l}\text { Safaee et al. } \\
\text { (2020) [62] }\end{array}$ & $\begin{array}{l}\text { Retrospective } \\
\quad \text { cohort study } \\
N: 938 \\
\text { M age: } 57 \\
\text { M:F 427:511 }\end{array}$ & $\begin{array}{l}\text { Spondylolis- } \\
\text { thesis } \\
\text { Deformity } \\
\text { Infection } \\
\text { Trauma } \\
\text { Tumour } \\
\text { Pseudoarthrosis }\end{array}$ & $\begin{array}{l}\text { Retroperitoneal } \\
n: 898 \\
\text { Transthoracic } \\
n: 40 \\
\text { Position: NA }\end{array}$ & Open & NA & $\begin{array}{l}\text { Single level } n \text { : } \\
350 \\
\text { Two level } n \text { : } \\
396 \\
\text { Three level } n \text { : } \\
164 \\
>\text { Four level } \\
n: 28\end{array}$ & $\mathrm{Y}$ \\
\hline
\end{tabular}

Table 5 Complications by approach type

\begin{tabular}{lllll}
\hline & Trans lap $n: 241$ & Trans open $n: 154$ & Retro another $n: 227$ & Retro open $n: 5106$ \\
\hline Average operative time & $180 \mathrm{~min}$ & $165 \mathrm{~min}$ & $250 \mathrm{~min}$ & $133 \mathrm{~min}$ \\
EBL & $103 \mathrm{ml}$ & $295 \mathrm{ml}$ & $204 \mathrm{ml}$ & $190 \mathrm{ml}$ \\
Average length of stay & 3.7 days & 4.25 days & 3.7 days & 4.5 days \\
Retrograde ejaculation & $22 \%$ & $12.2 \%$ & $2.2 \%$ & $2 \%$ \\
Vessel damage & $2.1 \%$ & $0.7 \%$ & $3.1 \%$ & $3.03 \%$ \\
DVT & $0.5 \%$ & NA & $0.35 \%$ & $1.4 \%$ \\
Haematoma formation & NA & NA & $0.7 \%$ & $0.6 \%$ \\
Visceral damage & $2.1 \%$ & NA & $0.4 \%$ & $0.37 \%$ \\
Hernia & NA & NA & NA & $1.3 \%$ \\
Wound infection: & NA & $0.7 \%$ & $0.35 \%$ & $1.9 \%$ \\
Ileus & $2.1 \%$ & $3.7 \%$ & NA & $5 \%$ \\
Dural tears & NA & $0.7 \%$ & NA & $0.04 \%$ \\
\hline
\end{tabular}

$\begin{array}{lrrrrrrr}\text { Zdeblick 2000 } & 1 & 12 & 0 & 12 & 9.2 \% & 0.08[-0.12,0.29] & 2000 \\ \text { Burkus 2002 } & 4 & 30 & 2 & 116 & 36.4 \% & 0.12[-0.01,0.24] & 2002 \\ \text { Chung 2003 } & 1 & 5 & 0 & 6 & 4.2 \% & 0.20[-0.20,0.60] & 2003 \\ \text { Escobar 2003 } & 3 & 12 & 1 & 38 & 13.9 \% & 0.22[-0.03,0.47] & 2003 \\ \text { Sasso 2003 } & 4 & 30 & 2 & 116 & 36.4 \% & 0.12[-0.01,0.24] & 2003 \\ \text { Lavelle 2014 } & 0 & 0 & 0 & 0 & & \text { Not estimable } 2014 \\ & & & & & & & \\ \text { Total (95\% Cl) } & 13 & & & & & \\ \text { Total events } & & & & & \end{array}$

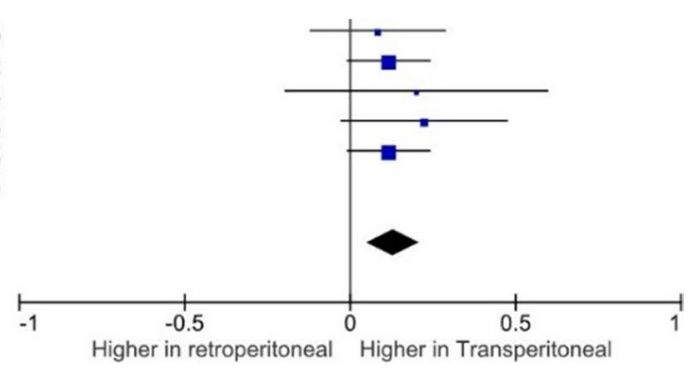

Fig. 2 Meta-analysis demonstrating rates of retrograde ejaculation between approaches

\section{Discussion}

\section{Use of access surgeons}

Anterior access to the spine is purported to provide better fusion rates; less blood loss, soft tissue injury, neural injury; and shorter operative time [5]. These benefits are weighed against the risk of vascular and visceral damage during exposure of the spine [58]. Efforts to mitigate these complications have included the use of "access surgeons" to provide safe passage. Conflicting evidence on the advantage conferred by the presence of general and vascular surgeons exists [32], a potential cause thought to be the variable training provided to spinal surgeons depending on healthcare system's practice of access surgeon use [1]. A recent meta-analysis found use of access surgeons is associated with increased rates of retrograde ejaculation (RE) and arterial injury $(p<0.001)$, with fewer postoperative complications noted than studies without their input 


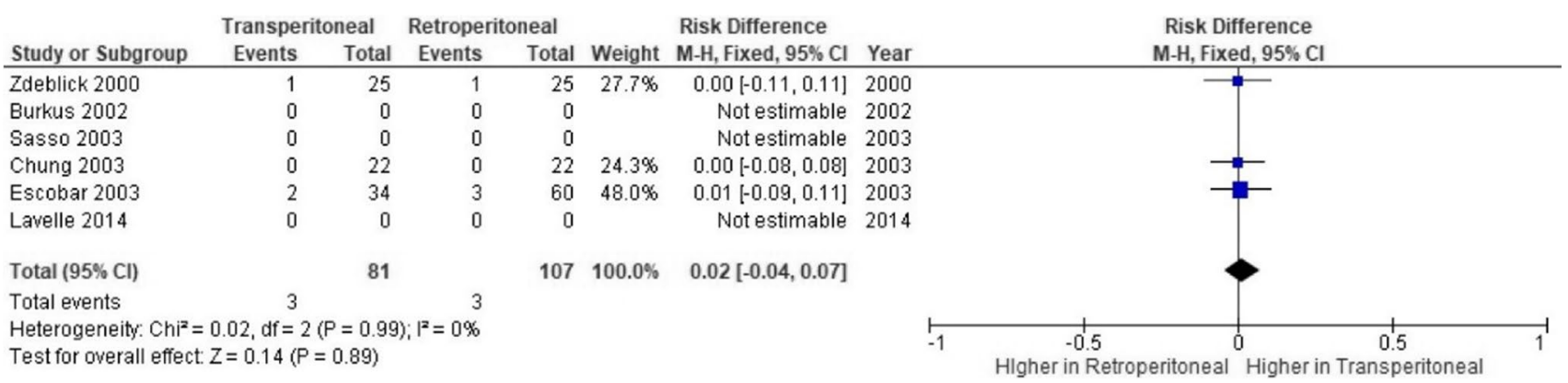

Fig. 3 Meta-analysis demonstrating rates of vessel injury between approaches

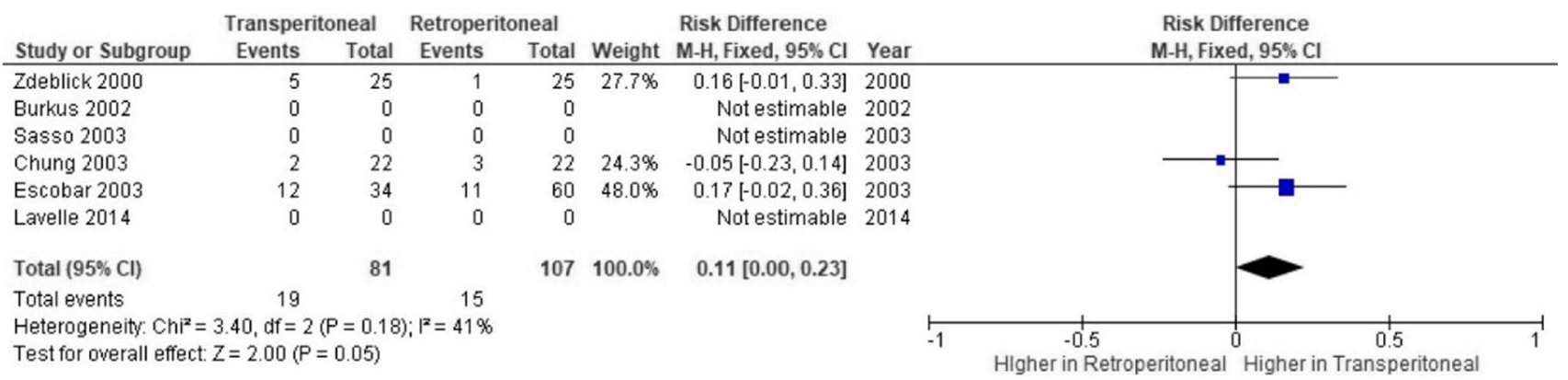

Fig. 4 Meta-analysis demonstrating rates of overall complications between approaches

[59]. This was felt likely to be in part due to the use of access surgeons predominantly in multilevel exposure, or difficult anatomical variances. Three studies [2, 44, 46] evaluated the role of access surgeons in the anterior spinal surgery reported a low vascular complication rate due to the presence of the access surgeon for the entirety of the operation. In contrast, Garg et al. [27] reported a $64 \%$ vascular injury occurring on approach despite the presence of a vascular surgeon. Whilst Chiriano et al. [17] previously emphasised the importance of access surgeons primarily for continued vascular trainee exposure to open surgery, three studies in this review [21, 25, 26] found a significant learning curve associated with their laparoscopic ALIF approach despite the presence of fully qualified general surgeons, with Cowles et al. [21] finding the conversion rate dropped from nearly 50 to $0 \%$ across the study time frame. The need for continued surgical resident exposure to ALIF procedures to ensure sufficiently experienced surgeons can provide access to the spine has been emphasised, regardless of surgical specialty [11]. Previous research on the impact of access surgeons on patient outcomes did not evaluate the relationship between level of surgical training obtained and complication rates outlined [59]; however, the validity of trainees as access surgeons in this role and familiarity of the access surgeon to the procedure warrant further evaluation given the high morbidity associated with complications in both transperitoneal and retroperitoneal approaches.

The impact of access surgeons on operative time has yet to established. Jarrett et al. [32] found similar rates of complication rates in patient groups with both access surgeons and no access surgeons present but noted that access surgeons were more likely to participate in multilevel exposure procedures and should be considered when factoring the impact of access surgeons on total operative time. Mogannam et al. [54] evaluated the impact of previous abdominal surgery on patient complication rates, with no significant increase in rates noted.

\section{Open vs. laparoscopic approaches}

Whilst advantages including shorter inpatient stays, fewer major complications, and less blood loss are associated with the laparoscopic approach [15], the risk of complications due to the anatomical variation at the level of approach, a steep learning curve, and the required knowledge of intra-abdominal anatomy [25] with longer operative times have led to widespread adoption of the open retroperitoneal approach. Cowles et al. [21] reported the highest conversion rate at $38 \%$, with risk factors including involvement of more than one spinal level, adhesions, bleeding, and levels other than L5/S1. The most common 
reason for conversion reported was to gain adequate control following vessel injury $[25,35]$, with Zdeblick et al. [74] reporting a $16 \%$ conversion rate due to inadequate exposure laparoscopically.

Estimated blood loss was less using non-open approaches, although this did not reach significance $(p=0.1)$, with longer operative times reported $(p=0.1)$. Blood loss has been indicated to be a poor objective measurement, due to the association of hidden blood loss in anterior lumbar interbody fusion operations [34]. Average length of stay was shorter in patients undergoing a non-open approach $(p=0.01)$. Complications arising from open procedures including wound infection and ileus were likely the cause for the longer inpatient stay in this cohort.

\section{Patient positioning}

Patient positioning is an important preoperative step to minimise anaesthetic risks, reduce risk of damage to structures during access to the spine, and the need for intraoperative repositioning [44]. A study evaluating the position of the great vessels in relation to the anterior spine found the bifurcation of the aorta was higher whilst in the prone position; the left common iliac vessels are at greater risk whilst patients are supine [7], with the lateral decubitus position thought to aid gravity mobilise abdominal contents including the great vessels away from the operative field [44]. Indeed, efforts to mitigate approach-related complications associated with ALIF have led to a rise in the use of the oblique lumbar interbody fusion (OLIF) [33], with favourable outcomes on rates of ileus compared to ALIF [72]. With the minimally invasive approach OLIF has a vascular complication rate than that of ALIF; however, further research on its long-term outcomes is required [73]. With a rise in the use of the lateral decubitus positioning with recently developed spinal instruments, morphometric evaluation of the great vessels indicates the L5/S1 window is larger in the supine position compared to that of the lateral decubitus position $(p<0.0001)$ [18]. The impact of patient positioning in the lazy lateral position offers a potential protection against risk to vascular structures, and patient outcomes demonstrated that the lazy lateral position yielded no vascular or visceral-associated patient complications [56]. Molloy et al. [56] felt the use of muscular windows during initial access contributed to the reduction in postoperative hernia rates. Reporting of patient positioning was inconsistent across the studies in this review; of those listed, supine was the most common, with three studies having patients in Trendelenburg [21, 26, 28], two in lateral decubitus [29, 44], and one in lithotomy [42], with small numbers preventing further analysis on their use.

\section{Vascular injury}

Vascular damage is a known complication arising whilst obtaining access to the spine [38]. Conflicting reports on the impact of factors contributing to vascular injury exist, including patient co-morbidities, spinal level [17], and laparoscopic vs. open approach [71]. The transperitoneal approach significantly increased the risk of vascular damage compared to retroperitoneally in one review [71], a finding refuted in other studies [2,31]. Risk of vessel injury was found to be higher in retroperitoneal approaches in this review, a difference not reaching significance $(p=0.07)$. Manunga et al. [46] noted their transperitoneal approach allowed them greater scope to mobilise the vessels thus aiding a reduction in damage, and greater operative control, congruent with Lucas et al. [42] finding the level of bifurcation required retraction of the iliac vessels far to the right with the retroperitoneal approach, the most common cause of vessel injury.

The ALIF approach at L4/L5 is limited by the rates of vascular injury and degree of vessel mobilisation required [73]. Research has failed to demonstrate a predictive correlation between anatomical pelvic parameters and overlying vessel location, indicating independent vascular planning may be required in the surgical approach [4] Chiriano et al. [17] found vascular injuries occurred most commonly during the L4/L5 approach during exposure between the left iliac artery and vein resulting in a significantly higher rate injury $(p<0.001)$, echoed by two studies in this review [26, 46], with Manunga et al. [46] finding $84.6 \%$ vessel injuries occurring at the L4/L5 exposure step using an open approach, most commonly due to avulsion of the iliac vessels. Multilevel exposure was also found to increase risk of vascular injury $(p<0.001)$ [27]. Type of cage and associated vascular complications were not discussed in the studies included in this review. Vascular complications have been found to be significantly more common with the use of threaded cages compared to non-threaded cages [64]. With the development of novel $3 \mathrm{D}$ porous cages in ALIF [50], impact of cage type on rates of vascular injury should be considered. Vascular complications including deep venous thrombosis (DVT) and pulmonary embolism (PE) have been reported to have a higher association in ALIF operation, with additional intraoperative posterior steps increasing the risk [31]. The highest incidence in this review occurred in the retroperitoneal open approach, although variation in reporting complications was prevalent in studies included. One study found a correlation $(p=0.022)$ between DVT and multilevel exposure, and males $(p=0.013)$ [27], with $10 \%$ DVTs occurring following extensive iliac reconstruction in another [46]. 


\section{Rates of RE}

Ejaculatory disorders (ED) are a commonly cited complication occurring in lumbar spinal surgeries, thought to occur primarily due to hypogastric plexus injury during access to the surgical corridor [40]. Factors associated with an increased risk of ED are obesity [8] and use of BMP. Neuroinflammation is a side effect of BMP investigated by the Food and Drug Administration (FDA), with indications that its use near the hypogastric plexus could result in complications arising from compound leakage. Burkus et al. [13] evaluated a series of anterior lumbar spine studies, finding a correlation with use of BMP and RE not reaching significance. Three studies in this review directly evaluated the effect of BMP in ALIF rates of RE [16, 20, 41], with mixed findings. Comer et al. [20] noted a found a significant association between use of BMP and rates of $\operatorname{RE}(p=0.0012)$. Carragee et al. [16] reported a similar finding ( $p=0.023)$, while Lubelski et al. [41] found no significant association $(p=1)$. Burkus et al. [14] found a significant correlation between urinary retention and use of BMP $(p=0.04)$, a complication not commonly listed in studies evaluating its efficacy; thus, a true incidence of the relationship is unknown.

The transperitoneal approach had a significantly higher association with RE compared to other approaches in this review $(p=0.0009)$. Evaluation of available data demonstrated $92 \%$ cases RE occurred at L5/S1 in two studies with significantly high rates [28, 35]. Similarly, Sasso et al. [65] found $85 \%$ of the patients who developed RE underwent exposure at the L5-S1 level. This finding was supported by Carragee et al. [16] who suggested the rates of RE in relation to the L5/S1 junction may be in part due to the bilateral injury risk associated with dissection of the aortic bifurcation. Given the FDA supported findings regarding the risk of BMP use, findings in two of these studies $[35,65]$ should be taken in context of an unclear breakdown of BMP use between control and intervention groups. Many studies reported their retrospective study method precluded accurate reporting rates of $\mathrm{RE}[46,62]$, which should be considered in the context of these findings.

\section{Visceral injury}

Visceral complications including ureteric injury, enterotomy, bladder rupture have all been found with the ALIF approach [71]. Reported rates of visceral injury were low from all approaches in this review. Three studies using a retroperitoneal approach reported peritoneal rupture rates ranging from 2.29 [1] to $16 \%$ [25] with no long-term complications. Boos et al. [9] reported all peritoneal rupture cases occurred primarily during extraperitoneal port insertion, early in the data collection stages of the study, and have thus attributed this to a learning curve.

\section{Postoperative ileus}

Rates of postoperative ileus in ALIF patients vary in the literature, with between 2 and 58\% reported [60], most commonly occurring between 2 and 5.4\% [43], and occurring in both transperitoneal and retroperitoneal approaches [68]. Open ALIF approaches in this review had higher rates of postoperative ileus reported compared to laparoscopic procedures, with no significant difference between transperitoneal and retroperitoneal approaches $(3.54 \%$ vs. $2.60 \% ; p>0.05)$. Bowel obstruction is a not uncommon complication associated with ALIF, with retroperitoneal structure mobilisation thought to be associated with the incidence of pseudo-obstruction [68]. Frantzides et al. [26] had one case of small bowel obstruction which they attributed to posterior peritoneum-cage adhesion and recommended peritoneal closure to reduce complications. Manunga et al. [46] identified their bowel ischemia from SMA injury as secondary to patient aneurysm identified postoperatively, recommending careful preoperative evaluation to identify patients at increased risk of complications.

\section{Neurological complications}

Dural tears are a complication in lumbar surgery associated with significant secondary complications including intracranial haematoma and dural fistulae [70]. Additionally, dural tears are associated with an increased risk of wound infections, neurological deficits, and perioperative systemic complications [67]. Three cases of dural tears were reported in this review, two occurring in the open retroperitoneal approach $[11,29]$ with an incidence rate of $0.04 \%$, and one in the transperitoneal open group $(0.7 \%)$ [35].

\section{Conclusion}

The open retroperitoneal approach is an established method for anterior lumbar interbody fusions with an acceptable safety profile. Transperitoneal studies are underpowered, with a dearth of data available. Research indicates a significantly higher risk of RE with this method; however, confounders including use of BMP and insufficient reporting of spinal level approaches should be considered. Laparoscopic approaches have shorter inpatient stays, with less postoperative complications including wound infection and ileus; however, its steep learning curve and longer operative times deter surgeons from its widespread adaptation. 
Funding Open Access funding provided by the IReL Consortium.

Data availability Not applicable.

Code availability Not applicable.

\section{Declarations}

Ethics approval Not applicable.

Conflict of interest The authors declare no competing interests.

Open Access This article is licensed under a Creative Commons Attribution 4.0 International License, which permits use, sharing, adaptation, distribution and reproduction in any medium or format, as long as you give appropriate credit to the original author(s) and the source, provide a link to the Creative Commons licence, and indicate if changes were made. The images or other third party material in this article are included in the article's Creative Commons licence, unless indicated otherwise in a credit line to the material. If material is not included in the article's Creative Commons licence and your intended use is not permitted by statutory regulation or exceeds the permitted use, you will need to obtain permission directly from the copyright holder. To view a copy of this licence, visit http://creativecommons.org/licenses/by/4.0/.

\section{References}

1. Amaral R, Ferreira R, Marchi L, Jensen R, Nogueira-Neto J, Pimenta L (2017) "Stand-alone anterior lumbar interbody fusioncomplications and perioperative results," (in eng). Rev Bras Ortop 52(5):569-574. https://doi.org/10.1016/j.rboe.2017.08.016

2. Asha MJ, Choksey MS, Shad A, Roberts P, Imray C (2012) The role of the vascular surgeon in anterior lumbar spine surgery (in eng). Br J Neurosurg 26(4):499-503. https://doi.org/10.3109/ 02688697.2012.680629

3. Aunoble S, Hoste D, Donkersloot P, Liquois F, Basso Y, Le Huec JC (2006) "Video-assisted ALIF with cage and anterior plate fixation for L5-S1 spondylolisthesis," (in eng). J Spinal Disord Tech 19(7):471476. https://doi.org/10.1097/01.bsd.0000211249.82823.d9

4. Baker JF, Chan JC, Moon BG, Robertson PA (2020) Relationship of aortic bifurcation with sacropelvic anatomy: application to anterior lumbar interbody fusion (in eng). Clin Anat. https:// doi.org/10.1002/ca.23598

5. Bassani R, Gregori F, Peretti G (2019) Evolution of the anterior approach in lumbar spine fusion (in eng). World Neurosurg 131:391-398. https://doi.org/10.1016/j.wneu.2019.07.023

6. Bassani R et al (2018) A new "keyhole" approach for multilevel anterior lumbar interbody fusion: the perinavel approach-technical note and literature review (in eng). Eur Spine J 27(8):1956-1963. https://doi.org/10.1007/s00586-018-5659-0

7. Bečulić H, Sladojević I, Jusić A, Skomorac R, Imamović M, Efendić A (2019) Morphometric study of the anatomic relationship between large retroperitoneal blood vessels and intervertebral discs of the distal segment of the lumbar spine: a clinical significance (in eng). Med Glas (Zenica) 16(2). https://doi.org/10.17392/1011-19

8. Bhambhvani HP, Kasman AM, Zhang CA, Hu SS, Eisenberg ML (2020) Delayed ejaculation after lumbar spine surgery: a claims database analysis (in eng). Global Spine J 2192568220962435. https://doi.org/10.1177/2192568220962435

9. Boos N, Kalberer F, Schoeb O (2001) Retroperitoneal endoscopically assisted minilaparotomy for anterior lumbar interbody fusion: technical feasibility and complications (in eng). Spine (Phila Pa 1976) 26(2)E1-E6. [Online]. Available: https://www. ncbi.nlm.nih.gov/pubmed/11176653

10. Brau SA (2002) Mini-open approach to the spine for anterior lumbar interbody fusion: description of the procedure, results and complications. Spine J 2(3):216-223. https://doi.org/10.1016/ s1529-9430(02)00184-5

11. Brewster L, Trueger N, Schermer C, Ghanayem A, Santaniello J (2008) Infraumbilical anterior retroperitoneal exposure of the lumbar spine in 128 consecutive patients (in eng). World J Surg 32(7):1414-1419. https://doi.org/10.1007/s00268-007-9433-4

12. Bumpass DB et al (2008) Implications of lumbar plexus anatomy for removal of total disc replacements through a posterior approach (in eng). Spine (Phila Pa 1976) 33(9):274-8. https://doi. org/10.1097/BRS.0b013e31816c90d6

13. Burkus JK, Dryer RF, Peloza JH (2013) Retrograde ejaculation following single-level anterior lumbar surgery with or without recombinant human bone morphogenetic protein- 2 in 5 randomized controlled trials: clinical article (in eng). J Neurosurg Spine 18(2):112-121. https://doi.org/10.3171/2012.10.SPINE 11908

14. Burkus JK, Gornet MF, Dickman CA, Zdeblick TA (2002) Anterior lumbar interbody fusion using rhBMP-2 with tapered interbody cages (in eng). J Spinal Disord Tech 15(5):337-349. https:// doi.org/10.1097/00024720-200210000-00001

15. Cammisa FP, Girardi FP, Antonacci A, Sandhu HS, Parvataneni HK (2001) Laparoscopic transperitoneal anterior lumbar interbody fusion with cylindrical threaded cortical allograft bone dowels (in eng). Orthopedics 24(3):235-239. [Online]. Available: https://www.ncbi.nlm.nih.gov/pubmed/11300287

16. Carragee EJ, Mitsunaga KA, Hurwitz EL, Scuderi GJ (2011) Retrograde ejaculation after anterior lumbar interbody fusion using rhBMP-2: a cohort controlled study (in eng). Spine J 11(6):511516. https://doi.org/10.1016/j.spinee.2011.02.013

17. Chiriano J, Abou-Zamzam AM, Urayeneza O, Zhang WW, Cheng W (2009) The role of the vascular surgeon in anterior retroperitoneal spine exposure: preservation of open surgical training (in eng). J Vasc Surg 50(1):148-151. https://doi.org/10.1016/j.jvs. 2009.01.007

18. Choi J, Rhee I, Ruparel S (2020) Assessment of great vessels for anterior access of L5/S1 using patient positioning (in eng). Asian Spine J 14(4):438-444. https://doi.org/10.31616/asj.2020.0078

19. Chung SK et al (2003) Comparative study of laparoscopic L5-S1 fusion versus open mini-ALIF, with a minimum 2-year follow-up. Eur Spine J 12(6):613-617. https://doi.org/10.1007/ s00586-003-0526-y

20. Comer GC, Smith MW, Hurwitz EL, Mitsunaga KA, Kessler R, Carragee EJ (2012) Retrograde ejaculation after anterior lumbar interbody fusion with and without bone morphogenetic protein-2 augmentation: a 10-year cohort controlled study (in eng). Spine J 12(10):881-890. https://doi.org/10.1016/j.spinee.2012.09.040

21. Cowles RA, Taheri PA, Sweeney JF, Graziano GP (2000) Efficacy of the laparoscopic approach for anterior lumbar spinal fusion (in eng). Surgery 128(4):589-596. https://doi.org/10.1067/msy.2000.108055

22. D'Souza M, Gendreau J, Feng A, Kim LH, Ho AL, Veeravagu A (2019) Robotic-assisted spine surgery: history, efficacy, cost, and future trends. Robot Surg 6:9-23. https://doi.org/10.2147/RSRR. S190720

23. Demura S et al (2020) Comparison of pulmonary function after selective anterior versus posterior fusion for the correction of thoracolumbar and lumbar adolescent idiopathic scoliosis. Global Spine J 10(4):433-437. https://doi.org/10.1177/2192568219859573

24. Elsamadicy AA et al (2017) Impact of surgical approach on complication rates after elective spinal fusion ( $\geq 3$ levels) for adult spine deformity (in eng). J Spine Surg 3(1):31-37. https://doi.org/ 10.21037/jss.2017.03.09 
25. Escobar E, Transfeldt E, Garvey T, Ogilvie J, Graber J, Schultz L (2003) Video-assisted versus open anterior lumbar spine fusion surgery: a comparison of four techniques and complications in 135 patients (in eng). Spine (Phila Pa 1976) 28(7):729-32. https://doi. org/10.1097/01.BRS.0000051912.04345.96

26. Frantzides CT et al (2006) L5-S1 laparoscopic anterior interbody fusion (in eng). JSLS 10(4):488-92, Oct-Dec 2006. [Online]. Available: https://www.ncbi.nlm.nih.gov/pubmed/17575763

27. Garg J, Woo K, Hirsch J, Bruffey JD, Dilley RB (2010) Vascular complications of exposure for anterior lumbar interbody fusion (in eng). J Vasc Surg 51(4):946-50; discussion 950. https://doi. org/10.1016/j.jvs.2009.11.039

28. Geerdes BP, Geukers CW, van Erp WF (2001) Laparoscopic spinal fusion of L4-L5 and L5-S1 (in eng). Surg Endosc 15(11):1308-1312. https://doi.org/10.1007/s004640000184

29. Hironaka Y, Morimoto T, Motoyama Y, Park YS, Nakase H (2013) Surgical management of minimally invasive anterior lumbar interbody fusion with stand-alone interbody cage for L4-5 degenerative disorders: clinical and radiographic findings (in eng). Neurol Med Chir (Tokyo) 53(12):861-869. https://doi.org/10.2176/nmc. oa2012-0379

30. Ikard RW (2006) Methods and complications of anterior exposure of the thoracic and lumbar spine (in eng). Arch Surg 141(10):10251034. https://doi.org/10.1001/archsurg.141.10.1025

31. Inamasu J, Guiot BH (2006) Vascular injury and complication in neurosurgical spine surgery (in eng). Acta Neurochir (Wien) 148(4):375-387. https://doi.org/10.1007/s00701-005-0669-1

32. Jarrett CD, Heller JG, Tsai L (2009) Anterior exposure of the lumbar spine with and without an "access surgeon": morbidity analysis of 265 consecutive cases (in eng). J Spinal Disord Tech 22(8):559-564. https://doi.org/10.1097/BSD.0b013e318192e326

33. Jin C, Jaiswal MS, Jeun SS, Ryu KS, Hur JW, Kim JS (2018) Outcomes of oblique lateral interbody fusion for degenerative lumbar disease in patients under or over 65 years of age (in eng). J Orthop Surg Res 13(1):38. https://doi.org/10.1186/s13018-018-0740-2

34. Ju H, Hart RA (2016) Hidden blood loss in anterior lumbar interbody fusion (ALIF) surgery (in eng). Orthop Traumatol Surg Res 102(1):67-70. https://doi.org/10.1016/j.otsr.2015.10.003

35. Kaiser MG, Haid RW, Subach BR, Miller JS, Smith CD, Rodts GE (2002) Comparison of the mini-open versus laparoscopic approach for anterior lumbar interbody fusion: a retrospective review (in eng). Neurosurgery 51(1):97-103; discussion 103-5. https://doi.org/10.1097/00006123-200207000-00015

36. Kapustka B et al (2020) Anterior lumbar interbody fusion (ALIF): biometrical results and own experiences (in eng). Neurosurg Rev 43(2):687-693. https://doi.org/10.1007/s10143-019-01108-1

37. Katsuura Y, Wright-Chisem J, Wright-Chisem A, Virk S, McAnany S (2020) The importance of surface technology in spinal fusion (in eng). HSS J 16(2):113-116. https://doi.org/10.1007/ s11420-020-09752-w

38. Kim DH, Kim TW, Kim MK, Park KH (2016) Iatrogenic vascular injury occurring during discectomy in a spondylodiscitis patient (in eng). Korean J Neurotrauma 12(2):171-174. https://doi.org/ 10.13004/kjnt.2016.12.2.171

39. Lavelle W, McLain RF, Rufo-Smith C, Gurd DP (2014) Prospective randomized controlled trial of The Stabilis Stand Alone Cage (SAC) versus Bagby and Kuslich (BAK) implants for anterior lumbar interbody fusion. Int J Spine Surg 8. https://doi.org/10. $14444 / 1008$

40. Lindley EM et al (2012) Retrograde ejaculation after anterior lumbar spine surgery (in eng). Spine (Phila Pa 1976) 37(20):1785-9. https://doi.org/10.1097/BRS.0b013e31825752bc

41. Lubelski D et al (2013) Urological complications following use of recombinant human bone morphogenetic protein-2 in anterior lumbar interbody fusion: presented at the 2012 Joint Spine Section
Meeting: clinical article (in eng). J Neurosurg Spine 18(2):126131. https://doi.org/10.3171/2012.11.SPINE12389

42. Lucas F, Emery E, Dudoit T, Berger L (2016) Influence of obesity on access-related complications during anterior lumbar spine interbody fusion (in eng). World Neurosurg 92:229-233. https:// doi.org/10.1016/j.wneu.2015.12.104

43. Mahoney JR, Barnes D, Pahl D (2019) Perforated ileus after L5S1 anterior lumbar interbody fusion: a case report presentation (in eng). AME Case Rep 3:21. https://doi.org/10.21037/acr.2019.07. 06

44. Malham GM, Wagner TP, Claydon MH (2019) Anterior lumbar interbody fusion in a lateral decubitus position: technique and outcomes in obese patients (in eng). J Spine Surg 5(4):433-442. https://doi.org/10.21037/jss.2019.09.09

45. Mamuti M et al (2016) Mini-open Anterior Lumbar Interbody Fusion for Recurrent Lumbar Disc Herniation Following Posterior Instrumentation. Spine (Phila Pa 1976) 41(18):E1104-E1114. https://doi.org/10.1097/BRS.0000000000001569

46. Manunga $\mathbf{J}$ et al (2020) Technical approach, outcomes, and exposure-related complications in patients undergoing anterior lumbar interbody fusion (in eng). J Vasc Surg. https://doi.org/10.1016/j. jvs.2020.06.129

47. Massaad E, Shankar GM, Shin JH (2021) Novel applications of spinal navigation in deformity and oncology surgery-beyond screw placement. Oper Neurosurg (Hagerstown) 21(Supp 1):S23S38. https://doi.org/10.1093/ons/opaa322

48. McLaughlin MR, Zhang JY, Subach BR, Haid RW, Rodts GE (1999) Laparoscopic anterior lumbar interbody fusion. Technical note (in eng). Neurosurg Focus 7(6):e8. [Online]. Available: https://www.ncbi.nlm.nih.gov/pubmed/16918207

49. Min JH, Jang JS, Lee SH (2007) Comparison of anterior- and posterior-approach instrumented lumbar interbody fusion for spondylolisthesis (in eng). J Neurosurg Spine 7(1):21-26. https:// doi.org/10.3171/SPI-07/07/021

50. Mobbs RJ, Parr WCH, Choy WJ, McEvoy A, Walsh WR, Phan K (2019) Anterior lumbar interbody fusion using a personalized approach: is custom the future of implants for anterior lumbar interbody fusion surgery? (in eng). World Neurosurg. https://doi. org/10.1016/j.wneu.2018.12.144

51. Mobbs RJ, Phan K, Assem Y, Pelletier M, Walsh WR (2016) Combination Ti/PEEK ALIF cage for anterior lumbar interbody fusion: early clinical and radiological results (in eng). J Clin Neurosci 34:94-99. https://doi.org/10.1016/j.jocn.2016.05.028

52. Mobbs RJ, Phan K, Daly D, Rao PJ, Lennox A (2016) Approachrelated complications of anterior lumbar interbody fusion: results of a combined spine and vascular surgical team (in eng). Global Spine J 6(2):147-54. https://doi.org/10.1055/s-0035-1557141

53. Mobbs RJ, Phan K, Malham G, Seex K, Rao PJ (2015) Lumbar interbody fusion: techniques, indications and comparison of interbody fusion options including PLIF, TLIF, MI-TLIF, OLIF/ATP, LLIF and ALIF (in eng). J Spine Surg 1(1):2-18. https://doi.org/ 10.3978/j.issn.2414-469X.2015.10.05

54. Mogannam A et al (2012) Effects of prior abdominal surgery, obesity, and lumbar spine level on anterior retroperitoneal exposure of the lumbar spine (in eng). Arch Surg 147(12):1130-1134. https:// doi.org/10.1001/archsurg.2012.1148

55. Moher D, Liberati A, Tetzlaff J, Altman DG, P Group (2009) Preferred reporting items for systematic reviews and meta-analyses: the PRISMA statement (in eng). BMJ 339:b2535. https://doi.org/ 10.1136/bmj.b2535

56. Molloy S, Butler JS, Benton A, Malhotra K, Selvadurai S, Agu O (2016) A new extensile anterolateral retroperitoneal approach for lumbar interbody fusion from L1 to S1: a prospective series with clinical outcomes (in eng). Spine J 16(6):786-91. https://doi.org/ 10.1016/j.spinee.2016.03.044 
57. Phan K, Fang BA, Maharaj MM, Lennox AF, Mobbs RJ (2017) Anterior lumbar interbody fusion in left-sided inferior vena cava and right-sided aortic arch (in eng). Orthop Surg 9(1):133-135. https://doi.org/10.1111/os.12306

58. Phan K, Thayaparan GK, Mobbs RJ (2015) Anterior lumbar interbody fusion versus transforaminal lumbar interbody fusionsystematic review and meta-analysis (in eng). Br J Neurosurg 29(5):705-711. https://doi.org/10.3109/02688697.2015.1036838

59. Phan K, Xu J, Scherman DB, Rao PJ, Mobbs RJ (2017) Anterior lumbar interbody fusion with and without an "access surgeon": a systematic review and meta-analysis (in eng). Spine (Phila Pa 1976) 42(10):E592-E601. https://doi.org/10.1097/BRS.00000 00000001905

60. Quraishi NA et al (2013) Access related complications in anterior lumbar surgery performed by spinal surgeons (in eng). Eur Spine J 22(Suppl 1):S16-20. https://doi.org/10.1007/s00586-012-2616-1

61. Qureshi R, Puvanesarajah V, Jain A, Shimer AL, Shen FH, Hassanzadeh H (2017) A comparison of anterior and posterior lumbar interbody fusions: complications, readmissions, discharge dispositions, and costs (in eng). Spine (Phila Pa 1976) 42(24):1865-1870. https://doi.org/10.1097/BRS.0000000000002248

62. Safaee MM et al (2020) The impact of obesity on perioperative complications in patients undergoing anterior lumbar interbody fusion (in eng). J Neurosurg Spine 1-10. https://doi.org/10.3171/ 2020.2.SPINE191418

63. Samudrala S, Khoo LT, Rhim SC, Fessler RG (1999) Complications during anterior surgery of the lumbar spine: an anatomically based study and review (in eng). Neurosurg Focus 7(6):e9. https:// doi.org/10.3171/foc.1999.7.6.10

64. Sasso RC, Best NM, Mummaneni PV, Reilly TM, Hussain SM (2005) Analysis of operative complications in a series of 471 anterior lumbar interbody fusion procedures (in eng). Spine (Phila $\mathrm{Pa}$ 1976) 30(6):670-4. https://doi.org/10.1097/01.brs.0000155423. 18218.75

65. Sasso RC, Kenneth Burkus J, LeHuec JC (2003) Retrograde ejaculation after anterior lumbar interbody fusion: transperitoneal versus retroperitoneal exposure (in eng). Spine (Phila Pa 1976) 28(10):1023-6. https://doi.org/10.1097/01.BRS.0000062965. 47779.EB

66. Siepe CJ et al (2015) Anterior stand-alone fusion revisited: a prospective clinical, X-ray and CT investigation," (in eng). Eur Spine J 24(4):838-851. https://doi.org/10.1007/s00586-014-3642-y
67. Takenaka S et al (2019) Dural tear is associated with an increased rate of other perioperative complications in primary lumbar spine surgery for degenerative diseases (in eng). Medicine (Baltimore) 98(1):e13970. https://doi.org/10.1097/MD.0000000000013970

68. Than KD et al (2011) Complication avoidance and management in anterior lumbar interbody fusion (in eng). Neurosurg Focus 31(4):E6. https://doi.org/10.3171/2011.7.FOCUS11141

69. Vazquez RM, Gireesan GT (2003) Balloon-assisted endoscopic retroperitoneal gasless (BERG) technique for anterior lumbar interbody fusion (ALIF). Surg Endosc 17(2):268-272. https:// doi.org/10.1007/s00464-002-8827-5

70. Wolff S, Kheirredine W, Riouallon G (2012) Surgical dural tears: prevalence and updated management protocol based on 1359 lumbar vertebra interventions (in eng). Orthop Traumatol Surg Res 98(8):879-886. https://doi.org/10.1016/j.otsr.2012.06.016

71. Wood KB, Devine J, Fischer D, Dettori JR, Janssen M (2010) Vascular injury in elective anterior lumbosacral surgery (in eng). Spine (Phila Pa 1976) 35(9 Suppl):S66-75. https://doi.org/10. 1097/BRS.0b013e3181d83411

72. $\mathrm{Xi} \mathrm{Z}$ et al (2020) Supine anterior lumbar interbody fusion versus lateral position oblique lumbar interbody fusion at L5-S1: a comparison of two approaches to the lumbosacral junction (in eng). $\mathrm{J}$ Clin Neurosci 82(Pt A):134-140. https://doi.org/10.1016/j.jocn. 2020.10 .043

73. Xu DS, Walker CT, Godzik J, Turner JD, Smith W, Uribe JS (2018) Minimally invasive anterior, lateral, and oblique lumbar interbody fusion: a literature review (in eng). Ann Transl Med 6(6):104. https://doi.org/10.21037/atm.2018.03.24

74. Zdeblick TA, David SM (2000) A prospective comparison of surgical approach for anterior L4-L5 fusion: laparoscopic versus mini anterior lumbar interbody fusion (in eng). Spine (Phila $\mathrm{Pa}$ 1976) 25(20):2682-7. https://doi.org/10.1097/00007632-20001 $0150-00023$

Publisher's note Springer Nature remains neutral with regard to jurisdictional claims in published maps and institutional affiliations. 